\title{
THE ROLE OF MUSIC AND MUSICIANS IN PROMOTING SOCIAL STABILITY IN THE COUNTRY
}

\author{
Eunice U. Ibekwe \\ Nnamdi Azikiwe University, Awka, Nigeria \\ *http://dx.doi.org/10.4314/ujah.v14i3.10
}

\section{Abstract}

Some of the prerequisites for promoting social stability in a country include, adequate security, socio-cultural and economic viability, political freedom, freedom of expression and association etc., On the other hand, a nation that lacks all these qualities is wrecked morally, socially, culturally and above all, most vulnerable to treason. In such instance, and obviously too, the portrayal of false identity, lawlessness, insubordination and the likes infiltrate or bedevil such a nation.. This paper critically examined the role music and musicians play in achieving stability in the country.

\section{Introduction}

In recent times people are passing through series of difficulties due to the problem of insecurity and social instability. In some parts of the country, people are perishing as a result of hunger, while others are faced with uncertainty of life, threat of wars, religious crises and its consequent BokoHaram issue, kidnapping, civil unrest, segregation, malnutrition, diseases, abduction and other numerous disheartening situations. This period, in a nutshell, is not different from the pre-colonial and colonial periods when people were sold into slavery, when poverty was seen as a curse and when all sorts of inhuman practices were given a boost by the powers that be, such as the local chiefs, the Obas, the Emirs and other wealthy tyrants of the time. The only 
The Role of Music and Musicians in Promoting Social Stability in the Country - Eunice U. Ibekwe, $\mathrm{PhD}$

difference between those periods and now is the absence of that monstrous appellation -'slavery', but ironically, the effect (of slavery) still remains, and if it is allowed to continue, one wonders what the next generation would turn out to be. Therefore in the face of all these vices bedeviling the country which have given rise to its present state of insecurity and instability, musicians and music have a holistic role to play. And this is the focus of the paper.

\section{Concepts of Music and Musician}

In this context, it is not out of place to discuss in general terms the concepts of music and musicians as they constitute the major framework of this essay. Many a time, people appreciate music just for what they think it is (-entertainment medium) and musicians for what they think they are (-entertainers). As a result they fail to comprehend the vital role music and musicians play in the proper functioning of events in human existence and thereby accord them little or no serious reputation in society. Music is more than ordinary entertainment phenomenon, according to Umezinwa (128) "to the owners and practitioners, it is a force, a living force that yields to various forms of meanings and interpretations. It is just not one thing but many things reviewed from a prism, which unifies all". Therefore, from these various forms of meanings and interpretations, one can rightly describe music as, a moral censor, a mobilizer, an educator, promoter of social and cultural values etc. As a moral censor and an educator for example, the following song on marriage issue educates parents on the need to allow their daughters make choice of marriage by themselves and condemns parents having upper hand or contracting marriage that is likely to cause disharmony and instability between the couple. 


\section{Marriage folk}

Nna mo, ina-eduzim na-eje n'ajo di?- My father, are you forcing me to marry a bad husband?

Nne mo, ina-eduzim na-eje n'ajo di?- My mother, are you forcing me to marry a bad husband?

Onye unu choro, a choghim ya -The person you desire, I don't want him

Onye ahu unu na- choghi yanwa bu obi mo-The one you do not want is my choice

Anyi g'ebi n'udo-

Anyi g'ebi n'ihunanya-

Chineke nyere anyi aka-

Chineke gozienu anyi -

Olisebr'uwa biko jikota anyi onu- Almighty God please unite together

Ife anyi cholu bu k'anyi bili n'udo- What we want is to live in peace

Ajo di ajoka Chineke biko - Bad husband is too horrible, God please.

Most parents are responsible for their children's marital problems due to their selfish ambition, either to cement an already existing relationship or for material gain at the expense of their children's comfort. The above song is a lesson which if put into consideration during marriage contract, will help reduce crimes and stresses associated with unhealthy union.

In the same instance, "A musician is a person who ... is involved in the art of' music making and above all takes it as a career". (Ibekwe,:35a) Based on this definition, various components of musicians emerge such as a composer, a vocal or instrumental performer, a conductor or director of choral /orchestral music, an arranger, a dancer and so on. Even musicologists who study the rudiments, theory and history of 
The Role of Music and Musicians in Promoting Social Stability in the Country - Eunice U. Ibekwe, $\mathrm{PhD}$

music in both traditional and western forms are also called musicians. (Ibekwe,35) The New International Webster's Comprehensive Dictionary of the English Language (838) defines a musician as "one skilled in music; especially, a professional performer". For the purpose of this discussion, Okafor, (6) provides a workable definition of a musician that places him/her above a mere entertainer, thus,

The musician has a role as a keeper of public conscience and as a man who has his hands on the social control lever. He guides the society; drawing, of course, from the collective wisdom and pool of knowledge and proverbs of his people. He foresees events like any poet, for a poet can point the way to come, even though the people following may not see it for the time being.

Musicians achieve all these through their music. Okafor, (7) goes further to say that, "many of our social comments, moral codes and guides are couched in music and songs" by these musicians. Take for instance, a mother who is instructing her child on the tenets of the community finds the product of musicians useful, so that the child grows up a responsible person devoid of social misfit. She renders the following song.

\section{Cradle Song}

Kelee onye muru gi

Kelee onye muru gi

Kelee onye toro gi

Nne gi gwa gi nuru

Nna gi gwa gi nuru

Greet your parents

Greet your parents

Greet your elder

Hear (obey) the instructions of your mother

Hear the instructions of your father 
Tuри onye ozo

Before heeding to those of another's

Ma gbaa mbo ruwere

Onye toro gi isi And persevere to respect your elders (Adapted from Okafor, 2005:55)

If the child obeys the mother's instruction, he /she will become a responsible person in future and would not bring stress to his / her parents and the society at large. Music (especially African) by its nature and purpose is a compendium of people's way of life. In other words, it represents people's tradition and no amount of stereotype conception can undermine its importance in any society. According to Ibekwe, (36)

musicians have designated duties which are embroiled in the power of their music to entertain, educate, socialize, symbolize, mobilize, motivate, sanitize, soothe, heal, exorcize, criticize and acculturate...Africans attach great values to cultural demeanors such as expressive power of song texts, symbolic and aesthetic disposition of costumes and endearing messages of body movements... (that) make culture statements any time music is performing. (Therefore), a musician is expected to follow or observe the standard laid down within the culture he is operating.

Obviously, the amount of recognition a musician receives in any society depends significantly on the effectiveness of his music in conveying the required message, which is based on the communities' understanding of the concept. Nzewi, (102) opinionates that, "the misunderstanding of ...(the) nature and logic (of African music) has given rise to a lot of misinformed and speculative theories about African's musical intellection", 
The Role of Music and Musicians in Promoting Social Stability in the Country - Eunice U. Ibekwe, $\mathrm{PhD}$

for that reason, musicians should take into consideration the people's expectations of them and avoid misrepresentations.

\section{The Concept of Insecurity / Social Instability;}

Insecurity according to The New International Webster's Comprehensive Dictionary of the English Language,(655) implies "the condition of being unsafe; liability to injury, loss or failure; uncertainty; instability"... From the above definition, insecurity appears to be synonymous with instability. On the other hand, social security from the same source means "any public system which provides welfare services for members of the community in need.(for instance)... A Federal program of old-age and unemployment insurance, public assistance to the blind, disabled, and dependent, and maternal and child welfare services administered by the social security administration" (1192). Given the above submission, one can then establish that social stability implies the provision of social services for the welfare of the citizenry, and that social instability obviously implies lack of social services which make people's lives unbearable, unsafe, and unstable. Therefore, being exposed to the consequences of insecurity and or social instability, it becomes clear what would be the situation of a country besieged with such vices. Musicians such as Celestine Ukwu of the blessed memory pictured this situation of instability and uncertainty through the following song, and revealed that no matter ones position in life one is still confronted by uncertainty of life. This is an advice for people to do things with moderation because no one knows tomorrow.

\section{TOMORROW IS UNCERTAIN}

Trust no future however pleasant it may seem

Trust no future however pleasant it may be

For what tomorrow has in store is so uncertain

Ride on with whatever you have in life 
For like Peter never go

Some pride (themselves) with what they have in mind

Some think that without them (there's) nothing like this world But the big question is;

Who had ever died and the world came to a standstill?

In this our funny world

There is so great rat-race to grab the world riches

Yet no one feels satisfied with whatever he or she has in life

Many are trampled

Many fall by the way side

But, hei! Stop and think

That when you are dead the world continues

The world continues without you

No matter your pride or position ...

(Philips 6361048 (PL) 1973, in Okafor, et al 1999;82 )

In a similar development, he encouraged people never to be despaired or discouraged no matter how bad the situation is. This is captured in his song titled, OKWUKWE NA NCHEKWUBE (Faith and Hope)

Ife nwelu mbido ga enwelili njedebe

Whatever has a beginning must have an end

O na-abu ife na-eme o dika o ma ebezi

When a thing happens it seems it will never come to an end

Ife melu anyi, k'anyi lunyelu Olisa

When we are in good times, let us pay tribute to God 
The Role of Music and Musicians in Promoting Social Stability in the Country - Eunice U. Ibekwe, $\mathrm{PhD}$

Ife mee anyi, k'anyi chekwube Olisa

When we are in hard times, let us hope in God

$K$ 'anyi ghalu nkolopu

Let us not despair

K'anyi welu okwukwe na nchekwube, ghalu nkolopu

Let us have faith and hope and forego despair

Welu okwukwe na nchekwbe

Have faith and hope

O na-abu ife na-eme ufodu e ekolopu

When some conditions prevail some people despair

O na-abu ife dado ndi ufodu fa e ekolopu

When temptations come some people despair

Anyi adi elota n'ife obuna nwelu mbido ga enwelili njedebe We do not remember that whatever has a beginning must have an end

Ife obuna a dado n'anyi k'anyi welu okwukwe na nchekwube Whatever befalls us, let us have faith and hope

Okwukwe na nchekwube ga azo anyi

Faith and hope will save us

Maka n'ife obuna e enwena mbido ga enwelili njedebe

Because whatever has a beginning must have an end (Okafor et al, 1999; 12) 
With the above instructions, one is therefore well informed on the challenges of life, and is also encouraged with the hope that one day or some time things may change or become better.

\section{The Role of Music and Musicians in the Promotion of Social Stability}

Good music promotes social stability, patriotism and gives good image to a nation. Many musicians and even individuals are concerned about making the country a better place. The issue and timely nature of the "rebranding process" initiated or launched on February 9, 2009 by the former Minister of Information and Culture, Professor Dora Akunyili, with the slogan, "Nigeria: Good People, Great Nation", is an attempt to create a better image for the country. This clarion call had earlier been given a boost by such musician as Nelly Uchendu in her songs,

\section{(1) BE A TRUE NIGERIAN}

Be a true Nigerian today

If we love our Country

We will make a greater progress

All those things we talk about

Will one day be forgotten

Only you can make a great Nigeria

Come let us make a great Nigeria

Sacrifice to build a great Nigeria (Nelly Uchendu, 1986)

\section{(2) MAKE A NEW NIGERIA}

Be a true Nigerian, do everything right

Always be patriotic

You will see you too can make Nigeria great

Don't be avaricious, don't ever mislead 
The Role of Music and Musicians in Promoting Social Stability in the Country - Eunice U. Ibekwe, $\mathrm{PhD}$

We must contribute now for the growth of our country

With good sanitation and excellent behavior

Let us be proud now to make Nigeria great (Nelly Uchendu, 1986) ( in Okafor ,2005;11-12)

These songs are calls for the people of Nigeria to be good people, be law abiding, and do what is right so that the country will be a better place for her citizenry. A musician is regarded as a 'watch-dog' to the happenings in his society. "A watchdog refers to one that guard against loss, waste, theft or undesirable practices". (Oguno, 157a) Music offers a perfect medium through which messages are communicated; even a message that is considered implicating, dangerous, hurting or abusive is conveyed through music without minding the consequences and provided it is aimed at bettering the condition of the oppressed. An example is captured in the song of Dan Maraya of Jos, rendered in Hausa Language. BABBAN MUTUM (HAUSA)

Mai Arzik,

Kana taka Mota Mai-isada

Ga ta da Na-u’ ran Sanyi

Ga ta muma da Rediyo

Kana ganin Talaka shi ba komai bane

Kana tsammanin shi ba kowa bane

Amma ka tuna fa

Ida Motar taka, ta kafe chikin lata

Shi dai wanna ta-lakan zaka

Nemo ya fitceta
Great man

You ride an expensive car

It is air-conditioned

It has radio
You despise the poor man

You think he is nothing

But remember this

When your car stuck in the mud

You will look for the poor

man to push it out 
Mai Dukiyan Great man

Kana zaune chikin Babban Gidan ka You live in your big house

Ga ta da Na-u' ran Sanyi It is air-conditioned

Ga manyan kujeru

You have big beds

Ga bubban Madafi

Ga Kuma Babban Zaure

You have a big kitchen

Kana ganin Talaka shi ba komai bane You despise the poor man

Baka taimakon sad a komai

Amma ka tuna fa

Shi dai Wannan Talakan

You have a big parlour

Da ba shi da komi

Shi ya dauki kasan

Da Ruwan

Da kuma sauran kayan

Da aka gina Gidan kan da shi

You will give him nothing

But remember this

It is the poor man

The lowly man of no

means

Who carried the sand

And carried the water

And carried the loads

For the building of your house

(Dan Maraya Jos in Okafor 2005; 365-366)

Musicians utilize music medium in no small measure to send messages across. According to Okafor, (10) a musician "shares a role of keeping a watchful eye on the goings-on in the society. $\mathrm{He}$ is therefore, a social critic and guides his people according to the prevailing norms. He foresees and he reflects. He has his hands on the social control lever". What it implies is that musicians are the society's spokes-men, the defender of the defenseless and pointers to social order. In Veno Marioghae's appeal for a positive change, she sent messages across in one of her Hits - NIGERIA GO SURVIVE If they tief our oil-o 
The Role of Music and Musicians in Promoting Social Stability in the Country - Eunice U. Ibekwe, $\mathrm{PhD}$

Even if they burn de oil-o

I say if they drain de oil-o

No matter how they try-o

Our roots dem strong for ground-o

Ancestors no go gree-o

The god of thunder and lightening

United should Nigeria

Refrain: Nigeria go survive

Africa go survive

My people go survive

Nigeria go survive

Andrew no check out-o

Stay and build your country

$\mathrm{Na}$ who go die for you-o

Blood is thicker than water

If Andrew do him work -o

And me Ido my own-o

If our leaders do dem best

Andrew go stay to help-o

Cocoa dey for West-o

Rubber bokwu for Bendel

Palm-oil e dey for East-o

Timber e dey for Benue-o

Hide and skin e dey-o

Cotton dey for North-o

(in Okafor, 2005:370)

Music provides avenues for correcting social disorder either by criticizing the constituted authority or a political power. Okafor, (10) clearly observes that, 
we have some musicians who got into trouble not only by attacking even the military but also by not respecting a political party in power which does not have a vision of the society as it should or shall be... whereas the musician may not sit at the seat of power, he has a say in what happens there. He has a say in what type of image those at the seat of power should project'.

Even at community levels, musicians are not always tolerated because of their out-spoken nature. Generally, music constitutes nuisance to deviants and law breakers even when directly or indirectly applied. Nevertheless, all these affirmations do not imply that musicians do not err, many musicians are sycophants, but that is not within the scope of this work. The type of music this paper is concerned with includes those that are culturally accepted or approved and those that promote social stability. Those of them that have little or no message at all to give are also not within the scope of this discourse no matter which of the groups that are involved.

Another important role music and musicians perform to address issue of social instability is the provision of jobs. The country is flooded with healthy men, women and youths who are jobless. Oguno, $(301 \mathrm{~b})$ decries that, talking of unemployment in a country like Nigeria where natural resources abound, looks ridiculous. He describes a situation where "excess oil accrue... gas is being flared, coal deposit abound, precious stones like granite abound in commercial quantity, palm plantation that was a major source of government income in years preceding independence have virtually been abandoned...Industries are not created and idle youths roam about the streets creating insecurity everywhere" as unfortunate. The greater percentage of crimes that ravage 
The Role of Music and Musicians in Promoting Social Stability in the Country - Eunice U. Ibekwe, $\mathrm{PhD}$

this country comes from these idle and restive citizens who would have been more productive if they were adequately engaged. In this direction, music and musicians have provided a very big relief and succor to many who engage themselves in one aspect of music business or the other for their livelihood. Many young boys and girls have become amateur musicians just to make both ends meet; some are involved in the sale of musical works. Even many of the school leavers have taken to dancing as market or business promoters instead of staying idle and causing trouble in society.

\section{Conclusion:}

Nigeria is a nation beset with a lot of problems which social instability/ insecurity is part of. These problems can only be eradicated if people are ready to shun self aggrandizement, and all the principle actors in the nation's struggle for better Nigeria project give a befitting image for the country. Musicians should point the way forward, and should not be busy fattening their pockets through praise singing, or presenting music that is counter-productive, a music that portrays the country in a negative image, instead they should use good music or jingles to enlighten the masses and even help the government to curb insecurity through songs and jingles that condemn deviant behaviours such as drug trafficking, fraud, and other related crimes and hence promote stability.

\section{Works Cited}

Ibekwe, E.U. "Performing Arts and Nation Building- The Role of Music". Interlink: A Journal of Research in Music.

Chukwuemeka C. Mbanugo (Ed) Awka: Abimac

Publishers. 4, 2009: 11-19. 
Ibekwe, E.U. "Musicians and the Philosophical Dimension of African Man". Awka Journal of Research in Music and the Arts. (AJRMA)) Nnamdi Azikiwe University, Awka. 7, 2010a: 33-45.

Ibekwe, E.U. "Music, Language and the Universal implication of Meaning". JANIM :Journal of the Association of Nigerian Musicologists, 4, 2010b: 66-73.

Nzewi, Meki. Musical Practice and Creativity. An African Traditional Perspective. Bayreuth: Iwalewa-Haus, University of Bayreut. 1991.

Oguno, N.C. "The Musician as a watch dog in a democracy: Echoes from songs of Patty Obasi and Ozoemena Nsugbe". Awka Journal of Research in Music and the Arts. (AJRMA)) Nnamdi Azikiwe University, Awka. 7, 2010a: 154-160.

Oguno, N.C. "The Nexus between Good Governance and Musical Arts". The Humanities \& Good Governance. A.B.C Chiegboka, T.C. Utoh-Ezeajugh , E.U. Ibekwe, C.C. Nwosu, N. C Oguno, and K.L. Nwadialor (Eds) . Nimo: Rex Charles and Partrick Ltd. 2012b.

Okafor, R.C. Music in Nigerian Society. Enugu: New Generation Books. 2005.

Okafor, R.C., Nwokike, F., Eziechi, C., Egudu, J. The Life and Works of Celestine Ukwu. Enugu: New Generation Books.1999. 
The Role of Music and Musicians in Promoting Social Stability in the Country - Eunice U. Ibekwe, $\mathrm{PhD}$

The New International Webster's Comprehensive Dictionary of the English Language Encyclopedic Edition. U.S.A: Typhoon Media Corporation 2010.

Umezinwa, E.C. "Igbo music, freedom and philosophy" Awka Journal of Research in Music and the Arts. (AJRMA)) Nnamdi Azikiwe University, Awka. 6, 2009: 128-136. 